\title{
Sam68 is a novel marker for aggressive neuroblastoma [Corrigendum]
}

Zhao X, Li Z, He B, et al. Onco Targets Ther. 2013;6: $1751-1760$.

In the author affiliation section on the first page, the affiliations were shown incorrectly. The correct author affiliations are as follows:

Xiaohong Zhao, ${ }^{1, *}$ Zuoqing Li, ${ }^{1}{ }^{1 *}$ Benfu He, ${ }^{2}$ Juncheng Liu, ${ }^{1}$ Suisheng Li, ${ }^{1}$ Li Zhou, ${ }^{1}$ Cuiling Pan, ${ }^{1}$ Zhe Yu, ${ }^{3} \mathrm{Zhe} \mathrm{Xu}^{1}$

${ }^{1}$ Department of Pediatric Surgery, First Affiliated Hospital of Sun Yat-sen University, Guangzhou, People's Republic of China; ${ }^{2}$ Oncology Department, PLA421 Hospital, Guangzhou, People's Republic of China; ${ }^{3}$ Laura Biotech Co., Ltd., Guangzhou, Guangdong Province, People's Republic of China

*These authors contributed equally to this work

\section{Publish your work in this journal}

OncoTargets and Therapy is an international, peer-reviewed, open access journal focusing on the pathological basis of all cancers, potential targets for therapy and treatment protocols employed to improve the management of cancer patients. The journal also focuses on the impact of management programs and new therapeutic agents and protocols on patient perspectives such as quality of life, adherence and satisfaction. The manuscript management system is completely online and includes a very quick and fair peer-review system, which is all easy to use. Visit http://www.dovepress.com/testimonials.php to read real quotes from published authors. 